ATOLL RESEARCH BULLETIN

NO. 573

OBSERVATIONS ON MASS SPAWNING OF SCLERACTINIAN CORALS IN GUADELOUPE

BY

PATRICK SCAPS

ISSUED BY

NATIONAL MUSEUM OF NATURAL HISTORY

SMITHSONIAN INSTITUTION

WASHINGTON, D.C., U.S.A.

MARCH 2010 


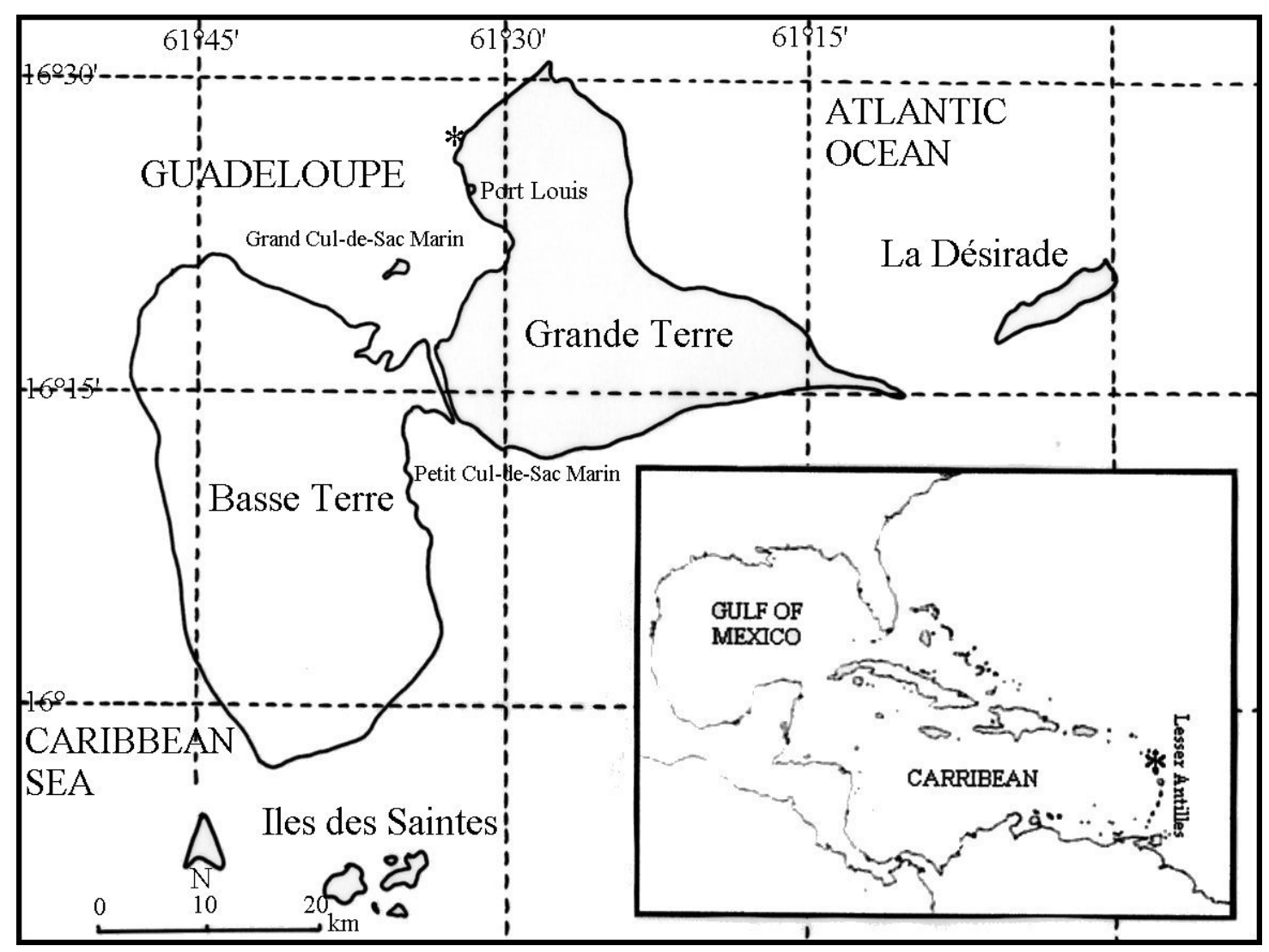

Figure 1. Location map of Guadeloupe showing location of the spawning observations (star). 


\title{
OBSERVATIONS ON MASS SPAWNING OF SCLERACTINIAN CORALS IN GUADELOUPE
}

\author{
BY
}

\author{
PATRICK SCAPS
}

\begin{abstract}
This study aimed to document coral spawning on a fringing reef in Guadeloupe (Lesser Antilles). In situ observations were made between 21:30 and 23:00 on days 6, 7 and 8 following the full moon of August 2008. We were unable to observe any sign of reproductive activity 6 days after the full moon. Colonies of the massive star coral Montastrea faveolata were noticed to release bundles of gametes 7 days after the full moon. Multi-species synchronous spawning of corals was observed 8 days after the full moon of August. A total of three species (Montastrea faveolata, Montastrea cavernosa and Diploria strigosa) broadcast spawned. Moreover, the same night, we documented the presence of zygotes near the tips of the tentacles of Eusmilia fastigiata indicating that this species is ready to spawn and the swarming of a large number of polychaetous annelids including syllid polychaetes in the genus Odontosyllis which were observed at the surface water producing brillant displays of green bioluminescence during mating swarms.
\end{abstract}

\section{INTRODUCTION}

Mass-spawning activities of scleractinian corals, i.e. the synchronous release of gametes by colonies of more than one broadcast-spawning coral species (Willis et al., 1985), have received much public and scientific attention since the extent of this phenomenon became known (Harrison et al., 1984, Babcock et al., 1986). In the Caribbean region, multispecies mass spawning has been observed at several localities (Wyers et al., 1991; Gittings et al.,1992; van Veghel, 1993 ; Steiner, 1995; de Graaf et al., 1999; Sánchez et al., 1999; Bastidias et al., 2005). However, there are relatively few studies that document these events by direct observations of several species at different geographical locations. In fact, many of the species-spawning periods have been inferred from the presence or absence of gonads in histological studies (Wyers, 1985; Szmant, 1991 ; Acosta and Zea, 1997; Villinski, 2003).

Guadeloupe is lined with approximately $250 \mathrm{~km}^{2}$ of reef which made one of the most important constituent of the Lesser Antilles (Spalding, 2004). However, the spawning behavior of reef invertebrates and especially scleractinian corals on Guadeloupe's reef has not been previously reported. Here we reported detailed observations on the timing of spawning for scleractinian corals following the full moons of August 2008.

Laboratoire de Biologie Animale, Université des Sciences et Technologies de Lille, 59655 Villeneuve d’Ascq Cédex, France. E-mail : patrick.scaps@univ-lille1.fr 


\section{METHODS}

Guadeloupe (Fig. 1) is located in the Lesser Antilles chain of the Caribbean and is composed of two main islands. The smaller, latter island of Guadeloupe proper is incongruously named Grande Terre (Big Land), while the larger mountainous volcanic island is equally strangely named Basse Terre (Low Land). These two are only separated by a narrow channel, the Rivière Salée, lined by dense mangroves and crossed by two bridges. The great bay, known as the Grand Cul-de-Sac Marin is strictly protected.

In situ observations of scleractinian corals spawning using SCUBA were made at the Les Arches site (The Archs) (16 $27^{\prime} 529^{\prime \prime}$ N, 61 $32^{\prime} 021^{\prime \prime}$ W) located near the town of Port Louis (approximately $5 \mathrm{kms}$ north from Port Louis) on the western coast of Grande Terre (Fig. 1). This site was selected because it is the site in the region of Port Louis which has the highest rate of coral cover and the highest biodiversity of scleractinian corals (personal observations). It is part of a fringing-reef complex which drops in a steep slope to a sandy bottom at $20 \mathrm{~m}$ approximately. A section of Les Arches, $100 \mathrm{~m}$ long and $50 \mathrm{~m}$ wide parallel to the shore and ranging from $6-17 \mathrm{~m}$ in depth, was selected for this study. In this section, colonies were observed between about 21.30 and 23.00 on days 6, 7 and 8 following the full moons of August $\left(16^{\text {rd }}\right)$ and September $\left(15^{\text {rd }}\right)$. Our timing of monitoring was based on previous records of coral spawning in the Caribbean. Underwater photographs were also taken to detail the spawning behavior.

\section{RESULTS}

We were unable to observe any reproduction of scleractinian coral 6 days after the full moon of August. We documented the release of egg sperm bundles from colonies of the massive star coral Montastrea faveolata (Ellis and Solander, 1786, Figs. 2 and 3), the dominant scleractinian on the reef, 7 days after the full moon of August between 22:05 and 22:40. All colonies observed were in water depths of between 5 to $16 \mathrm{~m}$. At approximately the same time the swarming of polychaetous annelids was noted (Fig. 2). 


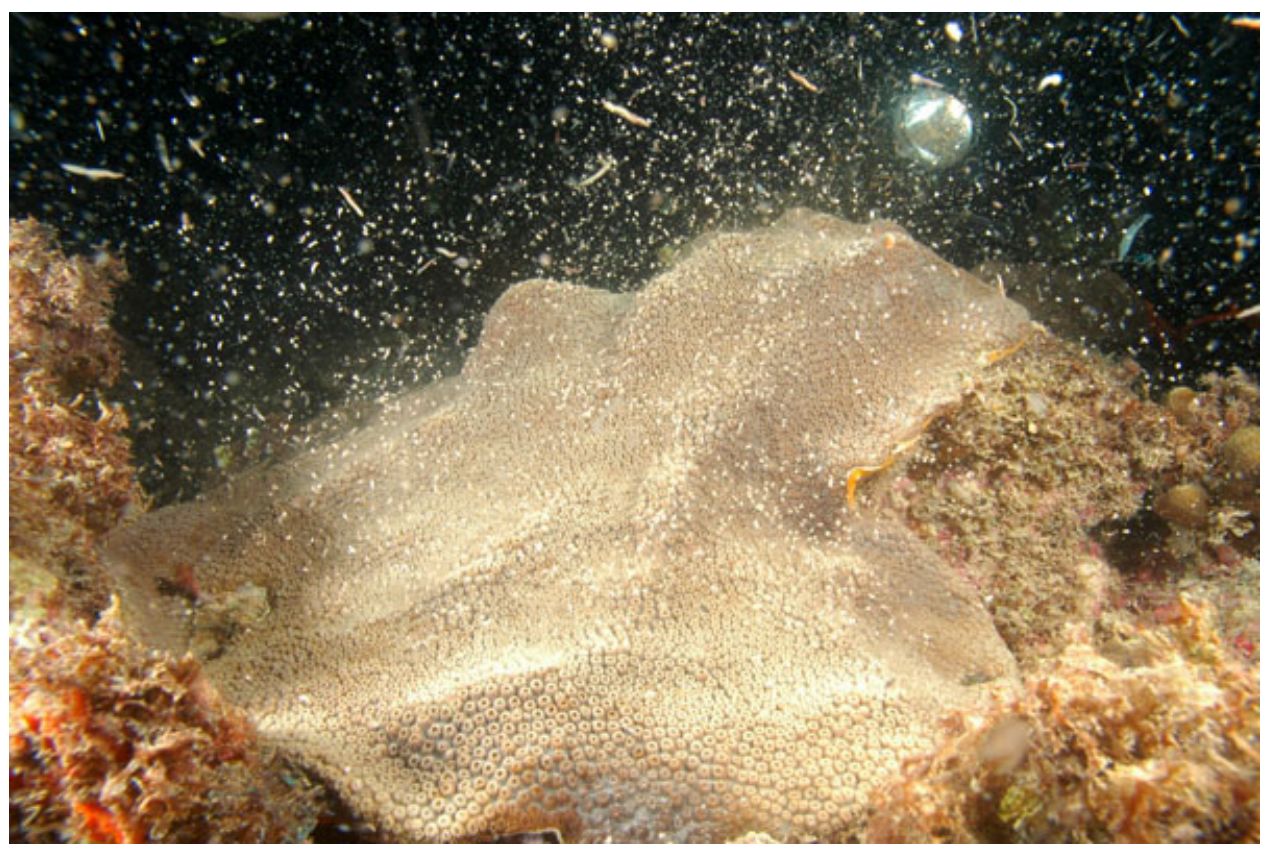

Figure 2. Mass spawning of the scleractinian coral Montastrea faveolata (Wednesday 23 August 2008, 22:28). Remark also the concomitant swarming of polychaetous annelids (A. Goyeau).

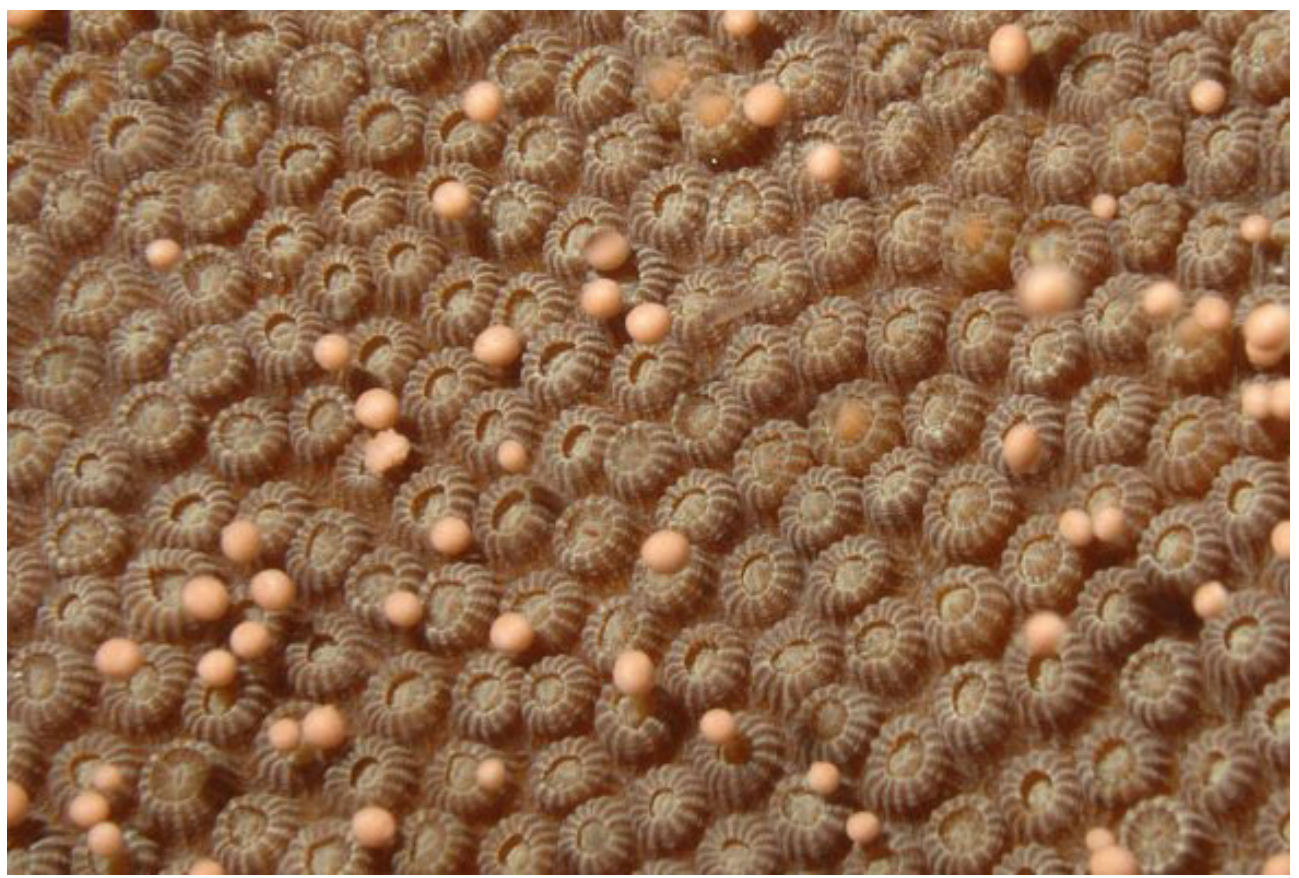

Figure 3. Montastrea faveolata colony releasing egg sperm bundles at night (Wednesday 23 August 2008, 22:08) (A. Goyeau). 


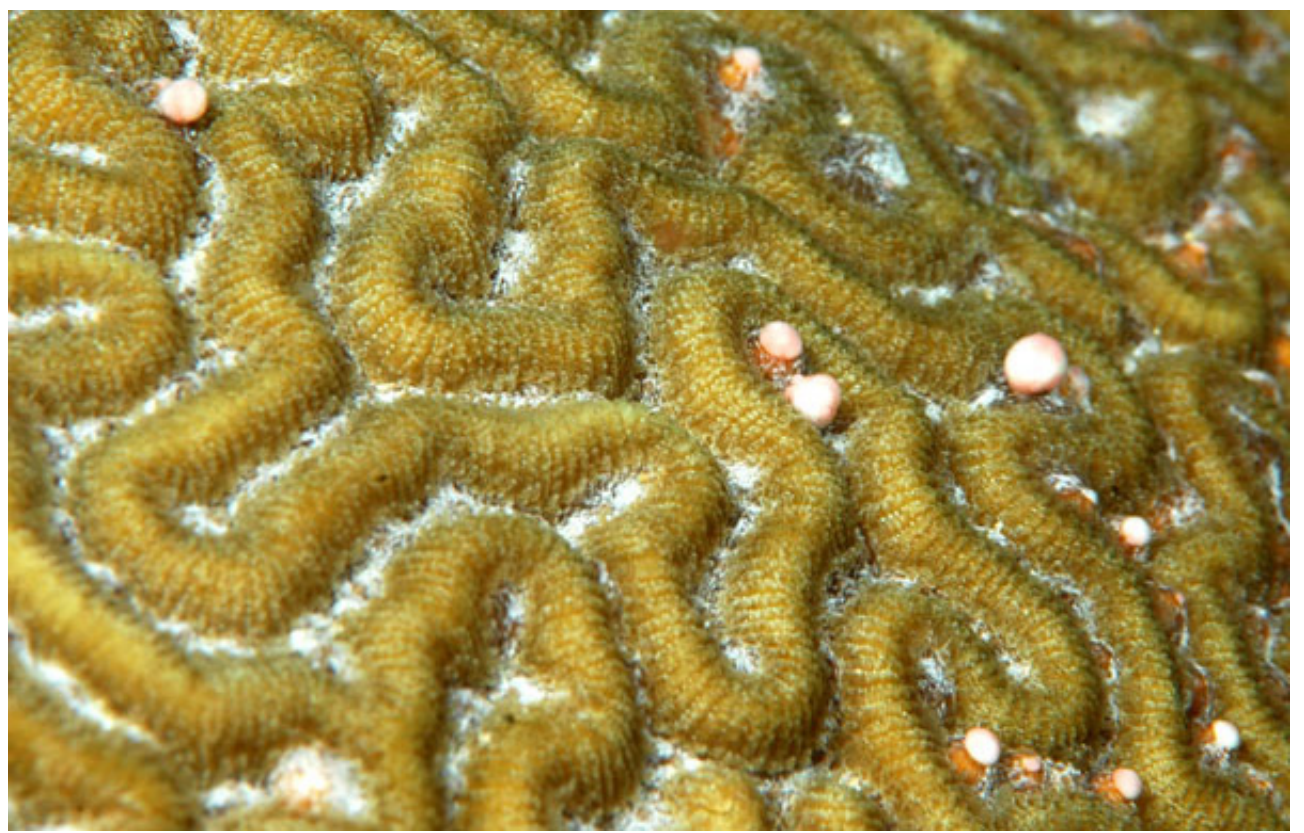

Figure 4. Mass spawning of the scleractinian coral Diploria strigosa (Thursday 24 August 2008, 22:15) (A. Goyeau).

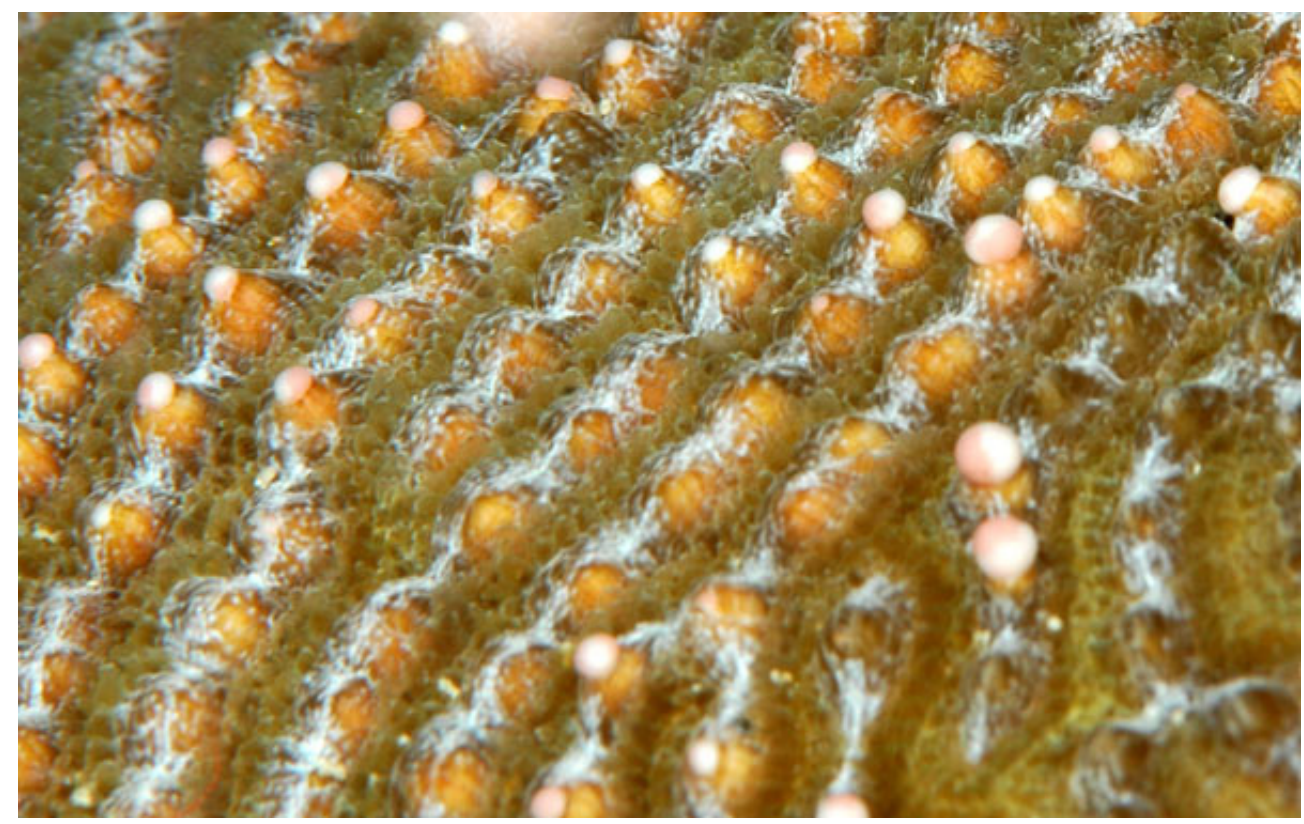

Figure 5. Diploria strigosa colony releasing egg sperm bundles at night (Thursday 24 August 2008, 22:16) (A. Goyeau). 
On the $8^{\text {th }}$ night after full moon of August we observed synchronous multispecific coral spawning. At 22:15 we noted the release of sperm from only one male colony of the large star coral Montastrea cavernosa (Linnaeus, 1766) at a depth of $12 \mathrm{~m}$. We also observed copious spawning of colonies of the brain coral Diploria strigosa (Dana, 1848) (Fig. 4 and 5) and of the massive star coral Montastrea faveolata in water depths of between 5 to $16 \mathrm{~m}$. Spawning started at 22:00 and ended at 22:35 for Diploria strigosa and started at 22:05 and ended at 22:35 for Montastrea faveolata. Moreover, zygotes were visible at the tip of the transparent tentacles of a single colony of Eusmilia fastigiata (Pallas, 1766) (Fig. 6). The zygotes were first noticed at 22:15 and were still visible at 22:50. According to the observations made by de Graaf et al., (1999), reproductive mode of Eusmilia fastigiata resembles brooding, however, unlike other brooders, $E$. fastigiata did not release well-developped planulae but zygotes in early developmental stages. Futhermore, the polychaete Hermodice carunculata (Pallas, 1766) was commonly seen preying on corals. The same night we observed the swarming of a large number of polychaetous annelids including syllid polychaetes in the genus Odontosyllis (Claparède, 1863) which were observed at the surface water producing brillant displays of green bioluminescence during mating swarms between 21:30 and 21:50.

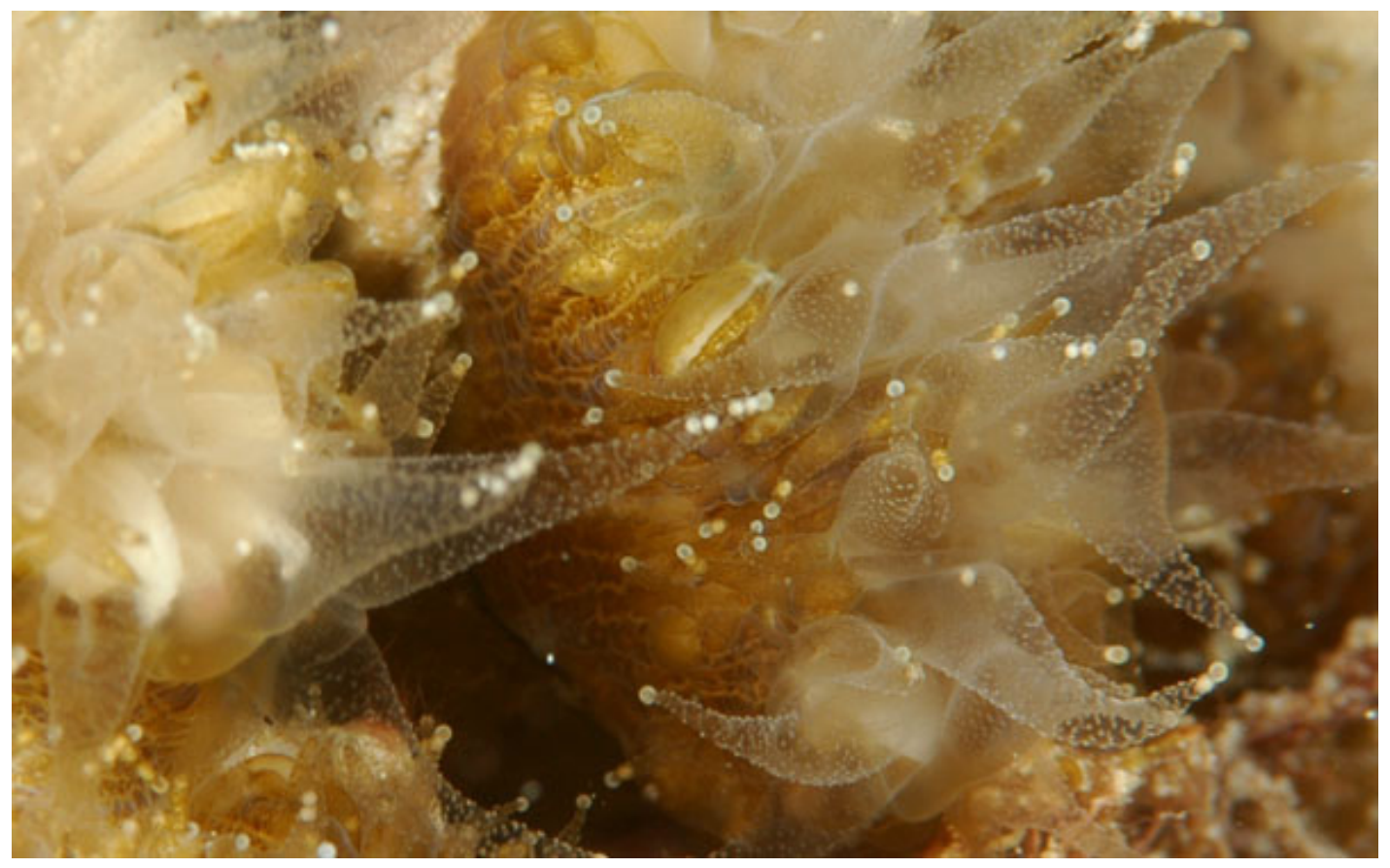

Figure 6. Eusmilia fastigiata with zygotes visible in the tentacles (Thursday 24 August 2008, 22:24) (A. Goyeau).

We were unable to observe any reproduction of scleractinian coral 6 and 8 days after the full moon of September. We noticed the release of egg/sperm bundles from colonies of Montastrea faveolata 7 days after the full moon of September between 21:30 and 22:00, but the September spawning event was less important in the number of colonies involved than the spawning event of August. 
In 2009, we again observed the spawning of corals approximately one week after the full moon of August $\left(6^{\text {rd }}\right)$ and September $\left(4^{\text {rd }}\right)$, confirming our previous observations. We documented the release of egg sperm bundles from colonies of Montastrea faveolata 6 days after the full moon of August between 22.15 and 22.40.

On the $7^{\text {th }}$ night after full moon of August we noticed spawning of colonies of Diploria strigosa and Montastrea faveolata. Spawning started at 22.05 and ended at 22.35 for Diploria strigosa and started at 22.05 and ended at 22.40 for Montastrea faveolata. We were unable to observe any reproduction of scleractinian coral 8 days after the full moon of August and 6 and 8 days after the full moon of September. We noticed copious spawning of colonies of Montastrea faveolata 7 days after the full moon of September between 21.50 and 22.25. Even colonies of Montastrea faveolata affected by yellow blotch syndrome were able to spawn in September (Fig. 7). Contrary to 2008, the September spawning event was more important than the spawning event of August.

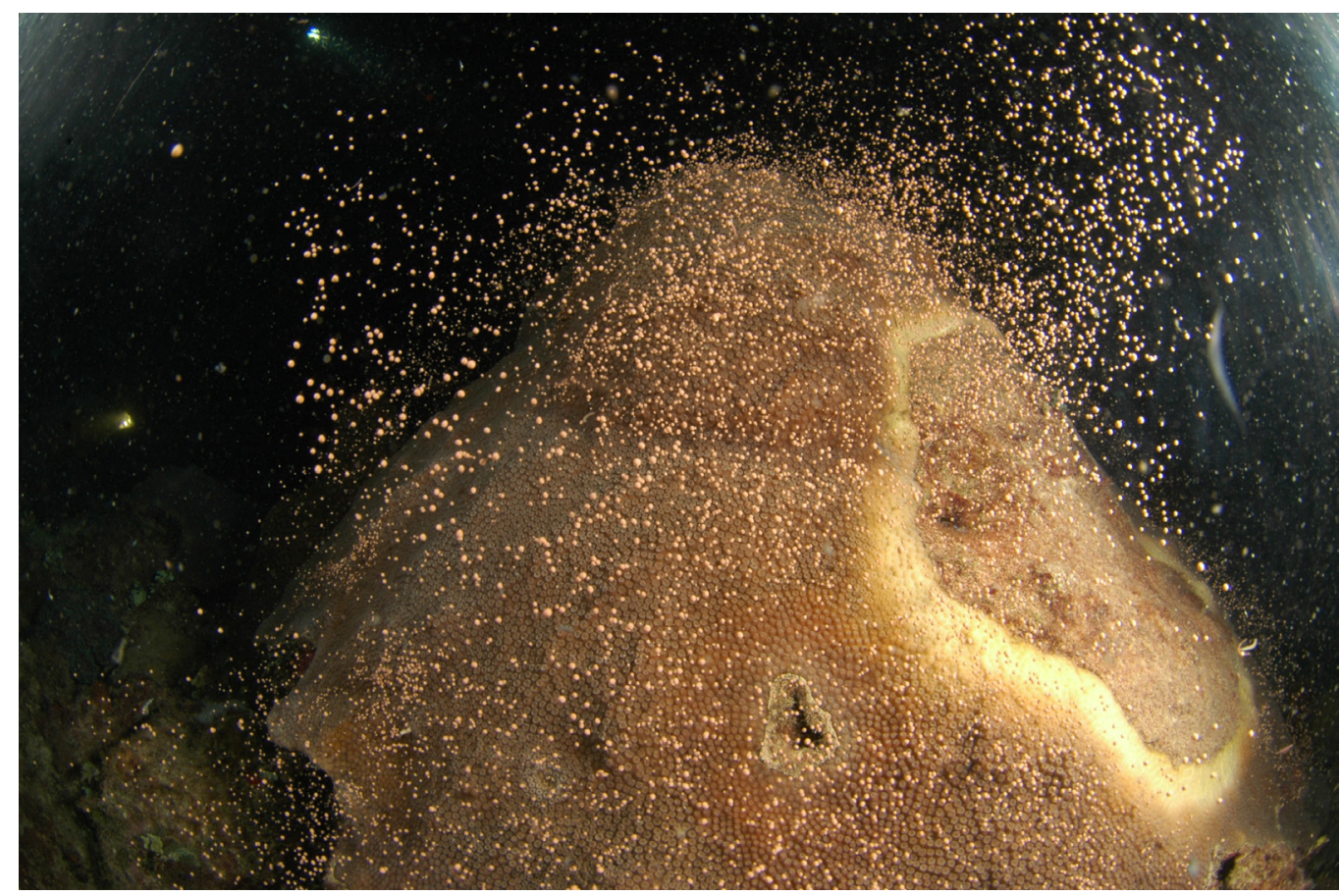

Figure. 7. Spawning of Montastrea faveolata with yellow blotch syndrome (Friday, 11 September 2009, 22.20) (A. Goyeau).

\section{DISCUSSION}

This study shows that three common Caribbean faviid species (Montastrea faveolata, M. cavernosa and Diploria strigosa) spawn in the night around one week after the full moon of August and/or September in Guadeloupe. Spawning occurs during the warmest season when water temperature reach $29^{\circ} \mathrm{C}$. M. faveolata is an important reefbuilding species found throughout the Caribbean. It is a member of the M. annularis species complex and has been separated from M. annularis (Ellis and Solander, 1786) and M. franksi (Gregory, 1895) as valid by Wiel and Knowlton, (1994). All three species 
are simultaneous hermaphrodites broadcast spawners. Each polyp within the colony produce a single gamete bundle containing both sperm and eggs (Levitan et al., 2004). During the spawning event, which lasts less than an hour (Szmant et al., 1997; Sánchez et al., 1999), these gamete bundles are extruded from polyp (Fig. 2) and float to the water surface where they burst, releasing their contents for fertilization. Diploria strigosa is also hermaphroditic broadcaster with male and female gametes occurring in separate but adjacent regions of the same mesentery. Contrary to the other two species observed spawning in our study site, M. cavernosa is gonochoric broadcaster.

The spawning patterns of M. faveolata, M. cavernosa and D. strigosa in Guadeloupe are very similar to previous reports for most localities in the Caribbean, i.e. colonies typically spawn once a year during the annual mass spawning event between 7 and 8 days after a full moon in late summer (typically in August or September) (Szmant, 1986, 1991; Soong, 1991; Wyers et al., 1991; Gittings et al., 1992; van Veghel, 1993, 1994; Steiner, 1995; Knowlton et al., 1997; Szmant et al., 1997; Acosta and Zea, 1997; Hagman et al., 1998; de Graaf et al., 1999; Sánchez et al.,1999; Villinski, 2003; Beaver et al., 2004; Bastidias et al., 2005). It seems that spawning is linked with seawater temperature, since all events take place during the warmest local period.

We also reported the presence of zygotes near the tip of the tentacles of a single colony of E. fastigiata indicating that this species is ready to spawn 8 nights after the full moon of August. According to the observations made by de Graaf et al. (1999), reproductive mode of E. fastigiata resembles brooding, however, unlike other brooders, E. fastigiata did not release well-developped planulae but zygotes in early developmental stages. Our observations with those of Bastidias et al. (1999), who also noticed the presence of zygotes at the tip of the tentacles in two colonies of E. fastigiata 7 nights after the full moon of August 1999. These zygotes were released the $8^{\text {th }}$ night on a Venezuelan inshore reef. In September, these same two colonies again showed zygotes; first noticed at 20:15 on the $7^{\text {th }}$ and still visible at $22: 15$ on the $8^{\text {th }}$ night after full moon, their last day of observation. However, there is a geographic variation in the timing of zygotes release. Thus, de Graaf et al. (1999), observed the release of zygotes from the tip of the tentacles of a colony for several hours each night over a period of at least four nights after the full moon of September and October 1996 on the reefs of Bonaire. A similar pattern of gamete release was observed in 1997. After the full moon of 16 October 1997 zygotes were released at night 5, 6 and 7 between 19:45 and 22:25.

Our observation of swarming by large number of marine polychaetes of the genus Odontosyllis 8 days after the full moon of August are consistent with other studies from the Caribbean indicating that syllid polychaetes in the genus Odontosyllis appear at the surface of the water shortly after sunset and luminesce and spawn for short periods (Market et al., 1961, Erdman, 1965, Fisher and Fisher, 1995, Gaston and Hall, 2000). Bioluminescence displays occur with lunar periodicity during reproductive swarming and, in the case of Odontosyllis luminosa, reproduction peaks during summer in Belize (Gaston and Hall, 2000). In Venezuela, bioluminescent polychaetes of the genus Odontosyllis were observed spawning at the water surface in August and at lower densities in September on an inshore reef but not on an offshore reef (Bastidias et al., 2005).

In conclusion, this report represents the first documented observation of multispecific, synchronous mass spawning of scleractinian corals in Guadeloupe. 


\section{ACKNOWLEDGMENTS}

This study would not have been possible without the logistical support of Alain Goyeau from Eden Plongée in Port Louis during the field work. I also wish to thank all the local SCUBA divers who assisted with diving and collection of field data. I am particularly grateful to Alain Goyeau for having provided the photographs.

\section{REFERENCES}

Acosta, A. and S. Zea

1997. Sexual reproduction of the reef coral Montastrea cavernosa (Scleractinia: Faviidae) in the Santa Marta area, Caribbean coast of Columbia. Marine Biology 128:141-148.

Babcock, R., G.D. Bull, P.L. Harrison, A.J. Heyward, J.K. Oliver, C.C. Wallace, and B.L. Willis.

1986. Synchronous spawning of 165 scleractinian coral species on the Great Barrier Reef. Marine Biology 90:379-394.

Bastidas, C., A. Cro' quer, A. L. Zubillaga, R. Ramos, V. Kortnik, C. Weinberger and L. M. Ma' rquez.

2005. Coral mass- and split-spawning at a coastal and an offshore Venezuelan reefs, southern Caribbean. Hydrobiologia 541:101-106.

Beaver, C. R., S. A. Earle, and J. W. Tunnell Jr.

2004. Mass spawning of reef corals within the Veracruz Reef System, Veracruz, Mexico. Coral Reefs 23:324.

De Graaf, M., G. J. Geertjes, and J. J. Videler

1999. Observations on spawning of scleractinian corals and other invertebrates on the reefs of Bonaire (Netherlands Antilles, Caribbean). Bulletin of Marine Science 54(1):189-194.

Erdman, D.S.

1965. Lunar periodicity in the swarming of luminescent worms, Odontosyllis octodentata Treadwell (Annelida) off La Parguera. P.R. Caribbean Journal of Science. 5:103-107

Fisher, A., and U, Fisher

2000. On the life-style and life-cycle of the luminescent polychaete Odontosyllis enopla (Annelida: Polychaeta). Invertebrate Biology 114:236-247.

Gaston, G.R, and J, Hall

2000. Lunar periodicity and bioluminescence of swarming Odontosyllis luminosa (Polychaeta: Syllidae) in Belize. Gulf and Caribbean Research 12: 47-51.

Gittings, S. R., G. S. Boland, J. P. Deslarzes, C. L. Combs, B. S. Holland and T. J. Bright

1992. Mass spawning and reproductive viability of reef corals at the East Flower Garden Bank, Northwest Gulf of Mexico. Bulletin of Marine Science 51:420428.

Hagman, D. K., S. R. Gittings and K. J. P. Deslarzes

1998. Timing, species participation, and environmental factors influencing annual 
mass spawning at the Flower Garden Banks (Northwest Gulf of Mexico). Gulf of Mexico Science 2:170-179.

Harrison, P.L., R. Babcock, G.D. Bull, J.K. Oliver, C.C. Wallace, and B.L. Willis

1984. Mass spawning in tropical reef corals. Science 223:1186-1189.

Knowlton, N., J. L. Mate' , H. M. Guzma' n, R. Rowan and J. Jara

1997. Direct evidence for reproductive isolation among the three species of the Montastraea annularis complex in Central America (Panama' and Honduras). Marine Biology 127:705-711.

Levitan, D. R., H. Fukami, J. Jara, D. Kline, T. M. McGovern, K. E. McGhee, C. A.

Swanson, and N. Knowlton

2004. Mechanisms of reproductive isolation among sympatric broadcasting spawning corals of the Montastrea annularis species complex. Evolution 58(2): 308-323.

Markert, R.E., B.J. Markert, and N.J. Vertres

1961. Lunar periodicity in spawning and luminescence in Odontosyllis enopla. Ecology 42:414-415.

Sánchez, J. A., E. M. Alvarado, M. F. Gil., H. Charry, O. L. Arenas, L. H. Chasqui, and R

P. Garcia

1999. Synchronous mass spawning of Montastrea annularis (Ellis \& Solander) and Montastrea faveolata (Ellis \& Solander) (Faviidae: Scleractinia) at Rosario islands, caribeban coast of Colombia. Bulletin of Marine Science 65(3):873879.

Soong, K.

1991. Sexual reproduction patterns of shallow water reef corals in Panama. Bulletin of Marine Science 49(3):832-846

Steiner, S.C.C.

1995. Spawning in scleractinian corals from SW Puerto Rico (West Indies). Bulletin of Marine Science 56:899-902.

Szmant, A. M.

1986. Reproductive ecology of Caribbean reef corals. Coral 43-54.

1991. Sexual reproduction by the Caribbean reef corals Montastrea annularis and $M$. cavernosa. Marine Ecology Progress Series 71:13-25.

Szmant, A. M., E. Weil, M. W. Miller, and D. E. Colon

1997. Hybridization within the species complex of the scleractinian coral Montastrea annularis. Marine Biology 129:561-572.

Spalding, M. D.

2004. A guide to the Coral Reefs of the Caribbean. University of California Press, Berkeley, Los Angeles, London, 256p.

van Veghel, M. L. J.

1993. Multiple species spawning on Curacao reefs. Bulletin of Marine Science 52: 1017-1021.

1994. Reproductive characteristics of the polymorphic Caribbean reef building coral Montastrea annularis: genetic, behavioural and morphometric aspects. Marine Ecology Progress Series 92:255-265. 
Villinski, J.T.

2003. Depth-independent reproductive characteristics for the Caribbean reef-building coral Montastrea faveolata. Marine Biology 142:1043-1053.

Weil, E, and N, Knowlton

1994. A multi-character analysis of the Caribbean coral Montastrea annularis (Ellis and Solander, 1786) and its two sibling species M. faveolata (Ellis and Solander, 1786) and Montastrea franksii (Gregory, 1895). Bulletin of Marine Science 55(1):151-175.

Willis, B.L., R.C. Babcock, G.D. Bull, P.L. Harrison, A.J. Heynard, J.K. Oliver and C.C. Wallace

1985. Patterns in the mass spawning of corals on the Great Barrier Reef from 19811984. $5^{\text {th }}$ International Coral Coral Reef Congress 4:343-348, Tahiti, France.

Wyers, S.C.

1985. Sexual reproduction of the coral Diploria strigosa (Scleractinia; Faviidae) in Bermuda: research in Progress. $5^{\text {th }}$ International Coral Coral Reef Congress 4: 301-306, Tahiti, France.

Wyers, S. C., H. S. Barnes and S. R. Smith

1991. Spawning of hermatypic corals in Bermuda: a pilot study. Hydrobiologia 216/217:109-116. 